\title{
Role of community figure in Healthy Indonesia Program with family approach (PIS-PK) in Banjarnegara District, Central Java
}

\author{
Mujiati, ${ }^{*}$ Eva Sulistiowati, Siti Nurhasanah \\ Center for Research and Development of Resources and Health Services, National Institute of Health Research and \\ Development, Ministry of Health of the Republic of Indonesia
}

\section{KEYWORDS}

Community figure

Healthy Indonesia

Program with

Family Approach (PIS-PK)

Role

\begin{abstract}
The involvement of community figure is one form of participation in health development, including in the Healthy Indonesia Program with Family Approach (PIS-PK). The purpose of this study was to determine the role of community figure in PIS-PK. The type of study was a qualitative study in one kelurahan which was included in the working area of Community Health Care (CHC) Banjarnegara 1 in Banjarnegara District, Central Java, which was chosen purposively. Data collection was done by in-depth interview. The key informants were community figure, namely from the kelurahan (kelurahan head and its staff) and community members who were considered community figure in the village. Data triangulation was done by conducting in-depth interview with the head and staff of community health center and the community. Data that has been obtained was analyzed thematically. The results of the study showed that community figure played an important role in the implementation of PISPK as sources of information about PIS-PK, helping field organizing, helping prepare complete families documents, assisting $\mathrm{CHC}$ staff and surveyor in home visits and helping solve problems that arise, and generally playing a role in the smooth implementation of PIS-PK. Social support from the local government and communities can be a motivation to continue to play a role in supporting the success of PIS-PK.
\end{abstract}

(C) The Journal 2020. This article is distributed under a Creative Commons Attribution-ShareAlike 4.0 International license.

\section{Introduction}

Direction of National Long-Term Development Plan 2005-2025 for the National Medium-Term Development Plan 2020-2024 (Phase IV) has 3 keywords: a solid economic structure, regional competitive advantage, and quality human resources. ${ }^{1}$ In 2015-2019 national development improving the quality of human life in Indonesia which is included in the 5th agenda of Nawa Cita through the Program Indonesia Pintar, Program Indonesia Sehat, and Program Indonesia Kerja dan Program Indonesia Sejahtera. In the Program Indonesia Sehat there are 3 pillars namely the Healthy Paradigm, Strengthening Health Services and the National Health Insurance. One effort to integrate into the 3 pillars is through the Family Approach.

\section{*Correspondence: mujiati.kemenkes@gmail.com}

Center for research and development of resources and health services, National Institute of Health Research and Development, Ministry of Health of The Republic of Indonesia Jl. Percetakan Negara No. 29 Jakarta, Indonesia
The Healthy Indonesia Program with Family Approach (PIS-PK) has begun to be implemented in stages since 2016 and is expected to reach total coverage in 2019. PIS-PK is one way for Community Health Center ( $\mathrm{CHC}$ ) to increase the reach of targets and get closer or increase access to health services by visiting families, so that the $\mathrm{CHC}$ does not only provide health services inside the building, but also outside the building by visiting family in its work area. ${ }^{2}$ In accordance with Minister of Health Regulation Number 43 of 2019 concerning Community Health Centers, in carrying out their duties, the $\mathrm{CHC}$ carries out the function of organizing public health efforts (Upaya Kesehatan Masyarakat/ UKM) and individual health efforts (Upaya Kesehatan Perseorangan/ UKP) in the working area. ${ }^{3}$ In carrying out these two functions, the $\mathrm{CHC}$ implements a family approach consisting of 12 indicators of healthy families, as an effort to integrate all efforts made by the $\mathrm{CHC}$. The twelve main indicators are priority areas for health problems, namely maternal and 
child health, nutrition, control of infectious and noncommunicable diseases as well as environmental health and behavior. ${ }^{4}$

As stated in the attachment of the Minister of Health Regulation Number 39 of 2016 concerning Guidelines for the Implementation of the Healthy Indonesia Program with Family Approach, efforts to achieve health development priorities in 2015-2019 in the Program Indonesia Sehat are carried out by utilizing all available potential, both from the central government, province, regency/ city, and society. Health development starts from the smallest unit of society, namely the family. The implementation of this family approach has three things that must be held or developed, namely instruments used at the family level, communication forums developed for contact with families, and the involvement of community workers as $\mathrm{CHC}$ partners. ${ }^{5}$

Community involvement such as community figure is one form of community participation in health development. According to the Pusat Pelatihan Gender dan Peningkatan Kualitas Perempuan Badan Koordinasi Keluarga Berencana Nasional (BKKBN), a community figure is someone who is influential and is characterized by his environment. This characterization is due to the influence of his position, abilities and expertise. All actions and remarks by community figure will be followed by the surrounding community. ${ }^{6}$ Community figure are proven to have an important role in the success of the health development program. The role of community figure will be different or specific to each program that is carried out, but the main objective is to encourage the community to participate in the program and support the success of the program. For example, community figure play an important role in socializing and bridging Family Planning and Family Development programs in East Kalimantan Province because of their emotional attachment to the local community. ${ }^{7}$ Another example is the success of the Integrated Development Post for NonCommunicable Diseases which is marked by the activeness of the population to the activity with the support of community figure in the Semarang city. ${ }^{8}$ Community figure is expected to play a role in every stage of the implementation of PIS-PK, starting from the preparation stage to the utilization of PIS-PK data in order to improve public health status. In addition, the role of community figure can be used as lessons learned for the success of health programs and things that need to be addressed in health development in other regions.

\section{Method}

This type of research was a qualitative study, carried out in one kelurahan which is included in the working area of the CHC Banjarnegara 1 in Banjarnegara District. Determination of the location of the study was done purposively, namely the work area of the $\mathrm{CHC}$ that will be visited by $\mathrm{CHC}$ in the framework of PIS-PK, so that researchers can find out the role of community figure starting from the preparation stage to monitoring and evaluating stage of PIS-PK activities.

Community data collection was done by in-depth interviews using in-depth interview guidelines. Key informants were community figure, namely from the kelurahan (kelurahan head and his apparatus) and community members who were considered as community figure in the community. Data triangulation also was done by conducting indepth interviews with the $\mathrm{CHC}$ and the community. In qualitative research, the number of informants is not the main thing as in quantitative research. In qualitative research, information gathering will stop when the answer or information from the informant is considered saturated. ${ }^{9}$

Data was analyzed thematically. The stages of thematic analysis carried out in this study were:

1. Collecting all data about role of community figure in PIS-PK

2. Reading all data from beginning to end

3. Coding text or information based on the stages of PIS-PK implementation

4. Ensure and re-evaluate whether the grouping of themes is appropriate.

Based on Technical Guidelines for Strengthening Management of PIS-PK, stages of PIS-PK implementation started with preparation stage, and then family/home visit, data input, preparation of proposed activity plans, implementation of problem interventions, and supervision, control 
and performance appraisal. ${ }^{2}$ However, after seeing and reading all the data from in-depth interviews, community figure in the working area of the $\mathrm{CHC}$ Banjarnegara I played a more important role in the preparation and family/home visit stages.

\section{Result}

\subsection{Overview of research site}

Banjarnegara District is one of the districts in Central Java Province which is located at a distance of $155 \mathrm{~km}$ to the west of the provincial capital. Astronomically located between 70.12 '- 70.31' South Latitude and 1090.29 '- 1090.45'.50' 'East Longitude. Banjarnegara District is bordered by four districts namely in the north bordering Pekalongan District and Batang District, in the east bordering Wonosobo District, in the south bordering Kebumen District, and in the west bordering Purbalingga District and Banyumas District. Administratively, Banjarnegara District is divided into 20 sub-districts, 266 villages, and 12 kelurahan. The working area of the $\mathrm{CHC}$ Banjarnegara 1 consists of 5 villages and 2 kelurahan.

According to the Decree of the Regent of Banjarnegara Number 440/1073/2018 concerning the Determination of Health Services Facilities in Urban Areas, Rural Areas and Remote Areas of Banjarnegara District, CHC Banjarnegara 1 is an urban $\mathrm{CHC}$. The $\mathrm{CHC}$ category is based on the capability of the organization including outpatient $\mathrm{CHC}$. The $\mathrm{CHC}$ was accredited in 2017. The management status of financial patterns is non-Regional Public Service Agency (non-Badan Layanan Umum Daerah/BLUD), with 6 working days a week, and $\mathrm{CHC}$ working hours 7 days a day. The working area of the $\mathrm{CHC}$ consists of 5 villages and 2 villages with a total number of 8,142 households.

Health workers in the $\mathrm{CHC}$ Banjarnegara 1 are 1 general practitioner, 1 dentist, 6 nurses, 12 midwives, 1 community health worker, 1 environmental health and 1 nutrition worker, and 1 pharmacy worker. There are 12 elderly Posbindu, 10 Posbindu PTM, and 32 Upaya Kesehatan Sekolah/UKS. There are 5 people who have been trained in the PIS-PK, with training executives from the Provincial Health Office and the District/City Health Office in 2018. The CHC has allocated a budget for the collection of healthy families and also provides a Healthy Family form.

Kelurahan that was the research locus is developing kelurahan with a population of 5,119 people and 1401 households. The existing health related government programs are the Program Keluarga Harapan (PKH), Program Kependudukan Keluarga Berencana Pembangunan Keluarga, Desa Broadband Terpadu, and Program Peningkatan Kesejahteraan Keluarga Melalui Pemberdayaan Masyarakat.

\subsection{Role of community figure in the PIS-PK implementation}

Associated with Program Peningkatan Kesejahteraan Keluarga Melalui Pemberdayaan Masyarakat, community figure were involved in PIS-PK. The involvement starts from the socialization activities. Community figure were involved by $\mathrm{CHC}$ in the socialization of PIS-PK to the community. Before conducting the socialization activities, first of all, the $\mathrm{CHC}$ provided information related to PIS-PK to community figure, including information about the purpose of PIS-PK, activities to be carried out in the framework of PIS-PK, and the benefits of PIS-PK, as said by the following informant:

"... we were informed at the Villages/ Kelurahan Health Forum that there would be a visit at each RT and RW. Then we continued the information during Kelompok Tani meetings, Kelompok Wanita Tani meetings, RT meetings, and then I continue (that information) to others, then ... coincidentally my wife was also in PKK so .. "please inform this...". Then FKK (Forum Kesehatan Keluarga) who the members are also representatives from each $R W$, so there are 12 $R W s$, to facilitate the dissemination of information. "(YS, community figure)

The quote above shows that after being given information about PIS-PK by $\mathrm{CHC}$, community figure pass the information on to the community, both through Kelompok Tani, Kelompok Wanita Tani, and others. This shows that community figure play a role as a source and provider of information about PIS-PK to the community.

In addition to providing information to the community about PIS-PK, community figure also 
play a role in Family/Home Visit Stage. After the CHC informs about a family/home visit within the framework of PIS-PK and provides details on which family data will be visited, community figure help remind people to prepare documents needed for home visits such as photocopies of Kartu Keluarga and showing the Kartu Jaminan Kesehatan Nasional or JKN card. This can be seen from the results of the interview, where the informant stated that they were involved in helping prepare family/home visits, as the following interview excerpts:

"When informing, it is recommended to submit a photocopy of KK and JKN (card)". (SR, community figure)

Other than that, community figure also assist CHC staff or surveyor who will conduct family/ home visits in compiling a list of families in the area. In the family/home visit process, community figure participate in accompanying the $\mathrm{CHC}$ staff or surveyor, so that community figure get an overview of the home visit process undertaken, like the following quote:

"We have partners in the community such as Mrs. $X Y$ (member) of the PKK, helping in arranging KK, delivering to the location." ( $\mathrm{SN}$, community figure)

From the accompanying family/home visit process, community figure got the picture that CHC staff asked all questions related to 12 PIS-PK indicators, took blood pressure measurements and provided counseling and advice on health problems found using the family health information package (Paket Informasi Kesehatan Keluarga/ PINKESGA).

"...the communication (CHC staff or surveyor) is quite clear and good, informative. Asking JKN and KK, filling out questionnaires (smoking, latrines, measured hypertension and so on). If no one at home, they will visit again. They also do counseling in accordance with problems in the family and directed to the $\mathrm{CHC}$ or Posbindu. " (SR, community figure)

Matters relating to PIS-PK activities according to some community figure have been communicated quite well by the $\mathrm{CHC}$. $\mathrm{CHC}$ usually coordinate with the Villages/ Kelurahan Health Forum and community figure facilitated by the Kelurahan. This communication aims to let community figure know the extent of PIS-PK activities in the community and also to know the problems that occur, so that they can help solve problems. Examples of problems that occur are the incomplete documents that must be prepared by the family at the time of the PIS-PK visit, as quoted from the following interview:

"From the community, sometimes the $K K$ does not exist/ does not have any. When I come there I want all family members to be there, but often can't meet all family members, so the information is obtained from family members at home. If indeed the data cannot be complete, so...please return to the house "( $\mathrm{YH}, \mathrm{CHC}$ Banjarnegara 1)

From the example problems above, community figure help remind families to be visited to prepare KK and JKN card, as well as remind the time agreement that has been made by the $\mathrm{CHC}$ staff or surveyor with the family for a repeat visit. Another obstacle is the community's suspicion of the CHC staff or surveyor who came, because previously the community had been visited by sales of health products with the lure of a free blood pressure check, so the $\mathrm{CHC}$ staff or surveyor who came with PIS-PK were rejected. Community figure or cadres assist the $\mathrm{CHC}$ staff or surveyor to visit families for PIS-PK, and with the presence of these community figure help the $\mathrm{CHC}$ staff or surveyor not to be suspected.

"... sometimes we go to the people and families to whom there is no one in the house, and this takes time. The good thing is that there are village cadres who accompany them so that someone knocks on the door so that the population doesn't have many questions or is suspicious. "( $\mathrm{YH}, \mathrm{CHC}$ Banjarnegara 1)

\subsection{PIS-PK stages involving community figure}

From the results of interviews with community figure and $\mathrm{CHC}$, it can be seen that community figure play a role in the implementation of PIS-PK. PIS-PK socialization activities to the community carried out by community figure were included in the Preparation Stage for the implementation of PIS-PK.

The activity of helping the community to prepare the necessary documents and accompanying and delivering $\mathrm{CHC}$ staff and surveyor to the community 


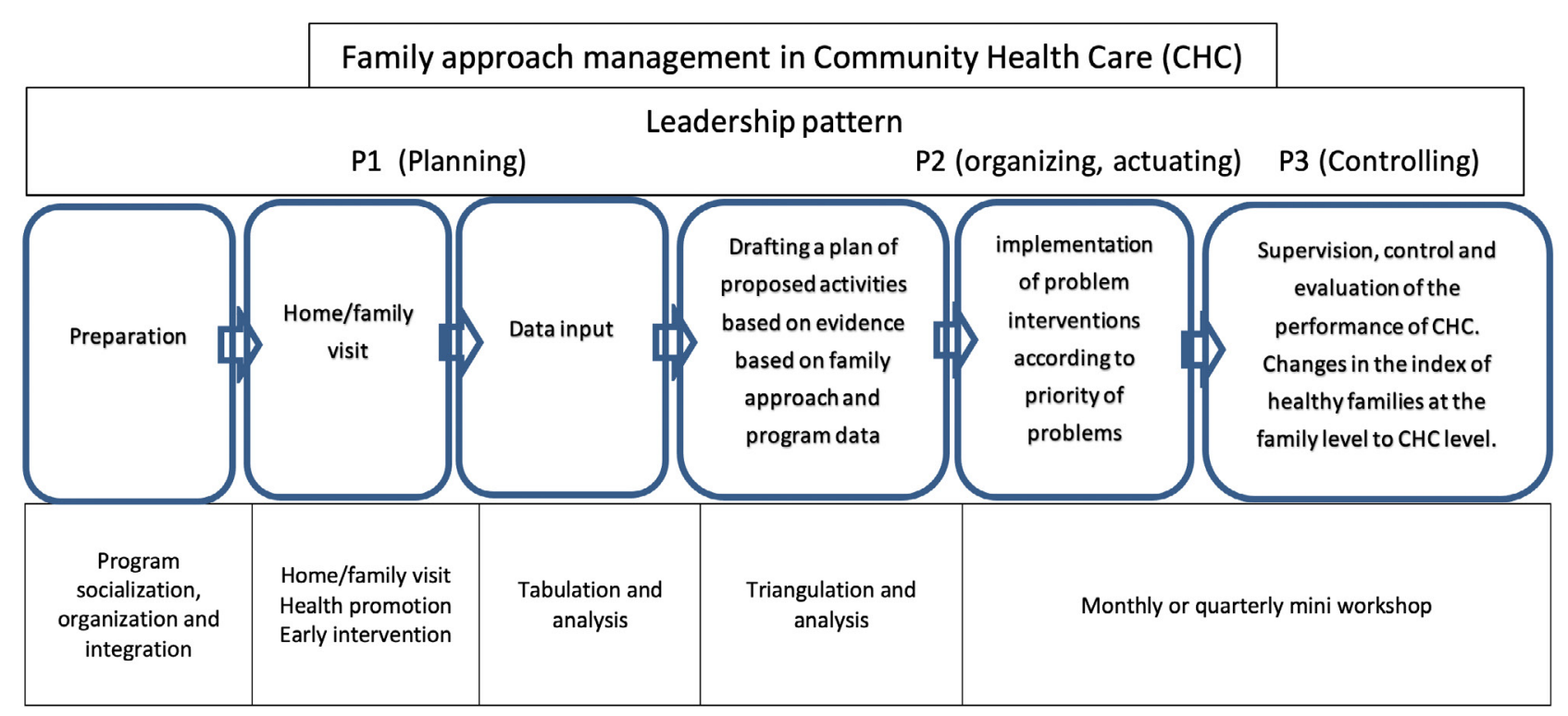

Figure 1. The stages of PIS-PK activities

Source: Technical Guidelines for Strengthening Management of PIS-PK, 2016

was the role of community figure included in the Family/Home Visit Stage. In addition, in this stage, community figure also play a role in helping to overcome obstacles or obstacles that occur.

\section{Discussion}

Health behavior is a person's response to a stimulus related to illness and disease, the health care system, food and beverage and the environment. ${ }^{10}$ Meanwhile, according to Green LW, et al health behavior is influenced by predisposing factors, enabling factors, and reinforcing factors. Social support includes the role of community figure including in reinforcing factors, namely factors that strengthen a person to behave as expected. ${ }^{11}$ Humans are an open unit composed of four aspects, namely biological, psychological, social and spiritual aspects. As social beings, humans are interdependent with other humans, so that changes in behavior can be influenced by humans around them. ${ }^{12}$

The role is a function that someone carries when occupying a characterization (position) in the social structure..$^{13}$ In this study, the role of community figure in PIS-PK is more on assist $\mathrm{CHC}$ in the preparation and implementation stages of PIS-PK. Based on Figure 1, the stages of PIS-PK activities are summarized in the management of a family approach that is integrated with the $\mathrm{CHC}$ management, starting from the planning process, the implementation movement to the process of supervision, control and assessment. ${ }^{2}$

In the Technical Guidelines for Strengthening PISPK Management it is stated that the implementation of PIS-PK by $\mathrm{CHC}$ will run well, if preparatory steps are carried out which include socialization, organizing, financing, and data collection preparation. In the preparation stage, program socialization, organization and integration are carried out. $\mathrm{CHC}$ need to conduct socialization on the family approach to the camat, RT/ RW chairperson, Lurah/ Village Head, heads of community organizations such as PKK, and community figure so that the implementation of the family approach receives support from the community. The results of this study indicate that at this stage, community figure play a role in assisting the socialization of PIS-PK by providing information about PIS-PK to the community both directly and indirectly. From the results of this study indicate that the socialization of PIS-PK activities is carried out in two ways namely socialization which is carried out in conjunction with mini workshop activities at the $\mathrm{CHC}$ and socialization at the Villages Health Forum. Both are by inviting and involving community figure. Socialization is important in the context of providing information and knowledge to the community which results in the community's decision to act or not act as expected. 
In the process of socialization, community figure are expected to influence or move the community to participate in health programs, including PIS-PK. The results of the PIS-PK evaluation in 8 provinces carried out by the Center for Research and Development for Public Health Efforts in 2016, generally showed that there were still many obstacles in the implementation of PIS-PK that caused the implementation of PIS-PK to be incompatible with the technical guidelines set. One of the obstacles is the lack of socialization of PISPK in the community. ${ }^{14}$

Community figure certainly become role models in the community so that if the socialization is carried out by community figure then the chances of success in health programs can be estimated to be quite large. Lawrence Green states that behavior can be formed due to imitating the behavior of others. ${ }^{10}$ The results of a study conducted by Yuliantina D on the implementation of Posyandu in Pandeglang District, Banten, showed that there was a relationship between the roles of community figure and participation society and the most dominant factor influencing community participation is the role of community figure. ${ }^{15}$

Another important thing in the successful implementation of the PIS-PK program is organization. Task management is one of the activities in organizing. In the Technical Guidance for Strengthening Management of PIS-PK it is stated that the arrangement of tasks does not have to be formally formed, but can be in the form of a network of coordination and collaboration between the internal $\mathrm{CHC}$ and external parties that are expected to support it. ${ }^{5}$

The results of this study showed that community figure also play a role in organizing, especially in organizing the field, which is helping to compile a list of households to be visited per RT/ RW. Field organizing is important because if the $\mathrm{CHC}$ staff or surveyor has not previously prepared a household listing, it will be difficult when he is in the field. A study conducted by Rahayu $T$ said that organizing included organizing human resources. The results of his study showed that the prevention and control program of dengue hemorrhagic fever was not running optimally because there was no organizing of the implementation team which resulted in a lack of team collaboration. ${ }^{16}$

The next step is a home visit. The role of community figure in this activity is to accompany the $\mathrm{CHC}$ staff or surveyor to come to the family, so that community figure indirectly gets a picture of what is asked and done by the $\mathrm{CHC}$ staff or surveyor. This figure can be used as information by community figure if there are community members who ask about what was done by the $\mathrm{CHC}$ staff or surveyor during home visits. This information is important because it can be a contribution to determine the attitudes and actions of the community and health workers towards health programs. For example, the results of a study conducted by Alifah $\mathrm{N}$ showed that nutrition workers did not inform the midwives of SOP promotion of midwives so that SOP was not implemented and midwives as program implementer worked in accordance with their own understanding. ${ }^{17}$ This certainly has a chance of not running the program according to SOP or technical guidelines that have been set.

Furthermore, support of community figure is the support obtained from interpersonal relationships that refer to pleasure, calmness, benefit assistance, in the form of verbal information received by a person or community from community figure that bring about behavioral effects. ${ }^{18}$ The support of community figure can be divided into emotional support which includes expressions of empathy, caring, and attention; award support which includes expressions of respect and encouragement to progress; instrumental support which includes direct assistance according to community needs; and informative support which includes advice, guidance, advice and feedback. ${ }^{18}$ Judging from this, the support of community figure in the PIS-PK in Banjarnegara District is more on informative and emotional support. The form of support from community leaders is almost the same as the results of a study conducted by Akbar MA, et al which showed that in the Desa Siaga Aktif activity, the form of community figure support in Kenongo Village, Gucialit Sub-district, Lumajang District in the form of emotional support, appreciation support, instrumental support, and informative support. ${ }^{19}$ The results of a study by Prayitno $B$ showed that in the context of developing a smoke-free area in Boyolali 
Town District, community leaders played a role as pioneers in the development of a Smoke-Free Zone, a motivator in the implementation of health education and promoters in order to prevent exposure to the effects of cigarette smoke. ${ }^{20}$ Another example of the role of community figure in gender responsive reproductive health are as counselors, mobilizers, motivators, facilitators, catalysts, and role models. ${ }^{6}$ The role of community figure as extension agents, mobilizers, motivators, facilitators, and catalysts in that study is the same as the results of this study.

\section{Conclusion}

Community figure in the working area of $\mathrm{CHC}$ Banjarnegara 1 play role in the PIS-PKimplementation, especially in the Preparation Stage and Family/Home Visit Stage. Role of community figure is as a source of PIS-PK information, helping field organizing, helping prepare complete families documents, assisting $\mathrm{CHC}$ staff and surveyor in home visits and helping to solve problems that arise. In order for community figure to continue to help the success of health programs including PIS-PK, social support from the local government and communities should be given.

\section{Acknowledgments}

The author would like to thank to the Head of Center for Resources and Health Services Research and Development, National Institute of Health Research and Development, who have funded this research through DIPA in 2018. Acknowledgments are also conveyed to the Head of the Research and Development Center Class 1 of Banjarnegara, Head of the Health Service Office of Banjarnegara District, Head of Community Health Center Banjarnegara 1 and all staff who have helped the research process.

\section{References}

1. Direktur Otonomi Kementerian PPN/BAPPENAS Rancangan teknokratik RPJMN 2020-2024, disampaikan dalam Rapat Koordinasi Penerapan e-Planning dalam Penyusunan RPJMD dan RKPD Bagi 171 Daerah Pilkada Serentak tahun 2018. Jakarta; 2018.

2. Kementerian Kesehatan Republik Indonesia. Pedoman Umum Program Indonesia Sehat dengan Pendekatan Keluarga. Jakarta; 2016.

3. Kementerian Kesehatan. Peraturan Menteri Kesehatan Republik Indonesia Nomor 43 Tahun 2019 tentang Pusat Kesehatan Masyarakat. Jakarta; 2019.

4. Kementerian Kesehatan Republik Indonesia. Modul Pelatihan Keluarga Sehat. Jakarta: Balai Besar Pelatihan Kesehatan Jakarta; 2017.

5. Kementerian Kesehatan Republik Indonesia. Peraturan Menteri Kesehatan Republik Indonesia Nomor 39 tahun 2016 tentang Pedoman Penyelenggaraan Program Indonesia Sehat dengan Pendekatan Keluarga. Jakarta; 2016.

6. Pusat Pelatihan Gender dan Peningkatan Kualitas Perempuan Badan Koordinasi Keluarga Berencana Nasional. Peran tokoh masyarakat dalam kesehatan reproduksi yang responsif gender [Internet]. 2008. Available from: https://balatbangbengkulu.files.wordpress. com/2010/05/toma.pdf

7. Anonymous. Toga dan Toma berperan dalam program KKBPK [Internet]. 2018. Available from: https://kaltim.antaranews.com/berita/45075/ toga-dan-toma-berperan-dalam-program-kkbpk

8. Umayana $\mathrm{H}$, Cahyati W. Dukungan keluarga dan tokoh masyarakat terhadap keaktifan penduduk ke posbindu penyakit tidak menular. J Kesehat Masy. 2015;11(1):96-101.

9. Kriyantono R. Teknik Praktis Riset Komunikasi. Jakarta: Kencana Prenada Media Group; 2006.

10. Notoatmodjo S. Pendidikan dan Perilaku Kesehatan. Jakarta: Rineka Cipta; 2003.

11. Green LW; Kreuter MW; Deeds SG; Partridge KB; Bartlett E. Health education planning: a diagnostic approach. Mayfield Publishing; 1980. $360 \mathrm{p}$.

12. Setiawati dan Dermawan. Proses pembelajaran dalam pendidikan kesehatan. Jakarta: Trans info media. 2008;43-59.

13. Bruce J. Biddle; and Edwin J Thomas. Role theory: concept and research. In: Edy Suhardono, editor. Teori peran: konsep, derivasi, dan implikasinya. Gramedia Pustaka Utama; 2016.

14. Puslitbang Upaya Kesehatan Masyarakat. Hasil Evaluasi Pelaksanaan Program Indonesia Sehat 
Dengan Pendekatan Keluarga (PIS-PK) Tahun 2016. Jakarta; 2016.

15. Yuliantina D. Hubungan peran petugas kesehatan, tokoh masyarakat dan partisipasi masyarakat (D/S) dalam pelaksanaan posyandu di Kabupaten Pandeglang Propinsi Banten [Internet]. 2019. Available from: http://etd.repository. ugm.ac.id/index.php?act=view\&buku_ i d = $53255 \&$ mo d = p e n elitia n detail\&sub=PenelitianDetail\&typ=html

16. Rahayu T. Evaluasi pelaksanaan program pencegahan dan penanggulangan penyakit demam berdarah dengue di wilayah kerja Puskesmas Ketapang 2 (Studi di Kecamatan Mentawa Baru Ketapang Kabupaten Kotawaringin Timur Provinsi Kalimantan Tengah). J Kesehat Masy. 2012;1(2):479-92.

17. Alifah N. Analisis sistem manajemen program pemberian ASI eksklusif di wilayah kerja Puskesmas Candilama Kota Semarang. J Kesehat Masy. 2012;1(2):97-107.
18. Smet B. Psikologi Kesehatan. Jakarta: PT. Grasindo; 1994.

19. Akbar MA, Gani HA, Istiaji E. Dukungan tokoh masyarakat dalam keberlangsungan Desa Siaga di Desa Kenongo Kecamatan Gucialit Kabupaten Lumajang [Internet]. https://repository.unej. ac.id/bitstream/handle/123456789/75190/ Muhammad Abdillah Akbar.pdf;sequence=1. 2019. Available from: https://repository.unej. ac.id/bitstream/handle/123456789/75190/ Muhammad Abdillah Akbar.pdf;sequence=1

20. Beja Prayitno. Peran tokoh masyarakat terhadap program promosi kesehatan dalam rangka pengembangan kawasan bebas asap rokok (kabar) (studi di Kecamatan Kota Boyolali) [Internet]. 2019. Available from: https:// digilib.uns.ac.id/dokumen/detail/18444/ Peran-tokoh-masyarakat-terhadapprogram-promosi-kesehatan-dalam-rangkapengembangan-kawasan-bebas-asap-rokokkabar-studi-di-Kecamatan-Kota-Boyolali 